\title{
FOOD INSECURITY AND CONFLICT EVENTS IN AFRICA*
}

\author{
Syed Mansoob MURSHED ${ }^{ \pm}$ \\ Muhammad BADIUZZAMAN* \\ Rashel HASAN"
}

\begin{abstract}
The aim of this paper is to examine the relationship between food insecurity and conflict events short of war in Africa, taking account of a host of mediating factors, including the degree of inequality, the level of development, democratic quality, quality of governance and the degree of government expenditure, which we incorporate into our analysis. Our results suggest that food price volatility does contribute significantly to conflict events measured by political events in Africa (ACLED). Greater democracy can engender more conflict, but in a non-linear fashion. The broader V-DEM participatory index of democracy also encourages more protest. Our governance variables are significant, emphasizing the salience of state capacity in this regard. An innovation of our study is the inclusion of inequality. We deploy two metrics of vertical inequality: the GINI coefficient and the broader V-DEM egalitarian index. The GINI index of income inequality has a counter-intuitive statistically insignificant sign, suggesting that greater income equality or middle-class share of income results in greater political unrest. We also utilize political measures of inter-group horizontal inequality which significantly engender conflict risk.
\end{abstract}

\footnotetext{
${ }^{ \pm}$International Institute of Social Studies (ISS), Erasmus University Rotterdam, The Netherlands and Coventry University, UK. Email: murshed@iss.nl. (Corresponding Author).

${ }^{*} \mathrm{PhD}$ Researcher, International Institute of Social Studies (ISS), Erasmus University Rotterdam, The Netherlands and Research Coordinator, Centre for Peace and Justice, BRAC University, Bangladesh. Email: badiuzzaman@iss.nl

\# Joint Director, Chief Economist’s Unit, Bangladesh Bank.Email: rasu_du@yahoo.com
}

\footnotetext{
* This paper was made possible by the NPRP award (NPRP 8-100-5-148) from the Qatar National Research Fund (a member of Qatar Foundation). The statements made herein are solely the responsibility of the authors. We would like to thank the managing editor of the journal, and support from the Centre for Financial and Corporate Integrity (CFI) at Coventry University.
} 


\section{Introduction}

It is now accepted that large scale violent internal or intra-state conflict is a major factor underlying developmental failure in low and middle income countries; see, for example, Collier et. Al (2003) and Murshed (2010). The seeds of conflict can be found in the prevalence of poverty, as poverty constrains livelihood choices to the point where the risks associated with violence become acceptable; equally internal conflict hampers economic growth and disadvantages development, such that poverty reduction in the presence of conflict is more arduous. Thus, internal conflict is of serious concern to the development community, including academics, policy makers at the national as well as international level and other practitioners. More recently, the inequality explanations for conflict are once more rising to the fore; see, Østby (2013), as well as Cederman, Gleditsch and Buhaug (2013). The aim of this paper is to examine the relationship between food insecurity and conflict events short of war (mass demonstrations, protests and so on) in Africa, taking into account the mediating role of the degree of development, the extent of government expenditure, the quality of political institutions and governance, as well as the role of inequality in this connection.

The principal form of war nowadays is civil war in developing countries. There were signs that civil war incidence (the number of civil wars and countries embroiled in them) and intensity (the number of fatalities) was on the wane (Gleditsch, 2008) before the beginning of this decade, but other forms of violence associated with mass protest and state suppression of these were also a matter of growing concern. With regard to the relationship between food insecurity and conflict, it is important to differentiate the type of conflict between wars (civil war and insurgency), and other conflict events short of war (mass demonstrations, protests and so on). We focus on the latter type of violence, focussing on these events in Africa.

Since time immemorial food shortages and food price increases have sparked social unrest. It needs to be borne in mind that the association between food insecurity ${ }^{1}$ or food price volatility and social unrest is indirect, including the mediating effect of a variety of other factors. It is indirect because a heightened sense of food insecurity brought about by rising or volatile food prices feeds into other fundamental causes of conflict, usually pre-existing grievances and state failure. Rising food prices lower the real income of food consumers, who for a given income are less able to purchase a fixed food basket without jeopardising their consumption of other goods and services, and the demand for basic foodstuffs is notoriously inelastic. Those affected are consumers (not net producers) of food, particularly low income households, but also middle-class consumers in developed countries who witness an erosion of their living standards. Clearly, poorer nations are more at the risk of conflict, following food price increases. Rising food prices are unlikely to be the sole cause of conflict, notwithstanding the examples of the Arab Spring in 2011, the revolutions in Europe in 1848, and famously the French revolution of 1789 which followed a bad harvest. History is replete with instances of food price increases following poor harvests that do not lead to major riots or revolutions, usually because of countervailing action mitigating the effects of food price increases by the state. Thus, for food price spikes to cause conflict they have to fuel existing grievances against the state or other groups, as well as the inability of the state to manage, suppress or placate

\footnotetext{
${ }^{1}$ Food insecurity can have several meanings. It can refer to the fragility of the supply of food, the diminution of food stocks, as well as the inability of consumers to obtain food or adequate nutrition due to famine, poverty, or the lack of entitlement to social protection. Food insecurity emanates from the volatility of food stocks as well as price shocks, which in a globalised world is only partially related to domestic factors, but also international prices. In developed countries, food insecurity mainly emanates from disruptions in the supply chain, the shortage of domestic production due to the volatility in farmer's incomes, resulting in the encouragement of domestic production through agriculture subsidies, as in the European Union.
} 
these grievances. Also, food prices have become increasingly globalised, and the transmission of international shock to domestic prices is more rapid in recent years.

The adverse effects of rising food insecurity are likely to be more acute in poorer countries with a poor record of economic growth and where poverty is widespread. Furthermore, food insecurity is more likely to lead to conflict, whether in the form of protest or war, in more unequal societies and where mitigating policies are not pursued by the state. Thus, the political system is important, as is the fiscal capacity of the state to undertake mitigating policies and good governance. Food insecurity ultimately can act as a tipping point that turns relative deprivation, grievances, as well as inter-group and inter-household inequality into conflict in the form of protest and/or war in the presence of weak state capacity. The current, cross-country empirical literature does not incorporate all these mediating factors into their empirical strategy, as can be observed from our brief literature review in section 2 . This is followed by a discussion of our empirical strategy for linking food insecurity and conflict in section 3 . Our empirical findings are presented in section 4, and section 5 concludes.

\section{Review of the Cross-Country Empirical Literature}

One of the earliest papers on this theme is by Miguel, Satynath and Sergenti (2004) who looked at the impact of economic growth on the risk of civil war. By treating economic growth as endogenous to conflict (as there is a reverse causality problem), and by using the rainfall rate as the instrument for growth in 41 African countries during 1980-99, Miguel, Satyanath and Sergenti (2004) find that growth is negatively and strongly related to civil war. A negative growth shock of five percentage points increases the likelihood of civil war by one-half in the following year. Food insecurity, on impact, is likely to have a negative impact on national income in poorer, low-income, developing countries.

Brinkman and Hendrix (2011) in a work for the World Food Programme (WFP) provide a general thematic overview of the link between food insecurity and violent conflict in its various forms including wars and demonstrations. They look at case studies of various developing countries, and explicit policy responses in 'fragile' states to rising food prices during the recent spike in 2007-08.

In a paper on food prices and political instability, Arezki and Brückner (2011) look at the effect of food prices on political instability in a cross-section of 120 countries in the 1970-2007 period. For prices they construct a country specific index of international food prices with a time invariant average value of net exports (net exports over GDP) of a food commodity for the entire sample period. When the international price of a food commodity rises, it has a negative wealth effect on the country's national income if the country is a net importer, and vice versa if it is a net exporter. They look at the effect of variations in international food prices on democracy/autocracy scores using the polity data, the incidence of civil war from the PRIOUppsala (UCDP) data set, and the Arthur Banks ${ }^{2}$ data on the number of riots and demonstrations. They find that food price increases lower democracy scores and increase the number of riots and demonstrations, as well as civil wars in low-income countries but not in rich countries. Furthermore, in the post cold war era the effects of food price increases are heightened for demonstrations and some other forms of conflict.

Bellemare (2014) analyses the effect of food price insecurity on conflict for the 1990-2011 period. The period of analysis is monthly rather than the standard annual analysis. He used the

\footnotetext{
${ }^{2}$ http://www.cntsdata.com/
} 
Food and Agricultural Organisation's (FAO) data on the index of international prices, as well as other food price indices, such as those for cereals, which weigh more heavily on the typical food basket in poor countries. His measure of food insecurity was both food price levels, and its volatility measured by a coefficient of variation for the proximate three months. The conflict variable is incidents for the month based on a LexisNexis search of English language sources of reports on incidents such as food riots. He followed an instrumental variable approach due to potential endogeneity of food prices and conflict, using natural disasters as an instrument, similar to the rainfall instrument employed by Miguel, Satyanath and Sergenti (2004). He finds that food price increases do cause more conflict, but not food price volatility.

Hendrix and Haggard (2015) in their study between 1961 and 2010 use a number of control variables covering unrest in Asian and African countries where they argue that $92 \%$ of the world's food insecurity lies. They utilise a food price index from UNCTAD, as well as polity scores, data on urban bias in agricultural policies, the degree of international trade openness, growth in national income (GDP) and levels of national income. Their dependent variable is urban unrest in Africa and Asia drawn from the PRIO Urban Social Disturbance database. This variable includes all forms of unrest, not just violent cases. The results are contingent on regime type with democracies and anocracies (polities with characteristics of both democracies and autocracies) more prone to unrest after food price rises, and rural bias also contributes to more urban unrest after a food crisis.

Smith (2014) in his analysis of urban unrest for African countries in the 1990-2012 period utilises domestic food prices obtained from the ILO, an instrumental variable approach using global grain prices and local rainfall as instruments. The controls are regime type, the share of urban population, share of youth in the population, GDP per capita, life expectancy and infant mortality. Changes in domestic food prices do contribute to urban unrest.

Weinberg and Bakker (2015) also utilise a measure of domestic food prices in their analysis covering 71 countries from 1972 to 2007. They convert global prices into a domestic price proxy using a consumer tax equivalent (CTE) based on data from the World Bank. Their measure of conflict is drawn from the Banks data set on riots, demonstrations and government crises. They control for regime type, urban population, ethnic fractionalisation and economic growth. Using count data methods changes in food prices do raise the risk of the conflict types described. Thus governments that prevent food price increases (the transmission of external price shocks) largely avoid food price based unrest, thus underlying the importance of countervailing policies when food crises occur.

Raleigh, Choi and Kniveton (2015) in their disaggregated study look at 113 African markets in 24 countries from 1997 to 2010. Their work also looks at climatic factors such as dryness and rainfall. Their conflict data is drawn from a PRIO data base (ACLED), which includes the locality of the conflict. The novelty of their approach is the simultaneous determination of local food commodity prices and conflict. Interventions in local markets can mitigate the effects of both conflict and climate factors on food prices. Natalini, Jones and Bravo (2015) look at which political or governance measure best captures the propensity for food price riots, finding that the World Bank's Political Instability and Absence of Violence is the best indicator. Within the transmission mechanism, the political stability of the state is important in turning food price increases to riots. They also identify food price thresholds, above which riots are more likely.

\section{Empirical Methodology}


Our empirical strategy investigates the effect of food insecurity (both level and volatility of food prices) on conflict events, while exploring the impact of different measures of institutional quality and inequality as explanatory variables with different specifications within this nexus. Our dependent variable on social unrest utilises data on conflict events is obtained from the PRIO-ACLED (armed conflict location and event data project) data set which records protests and political violence for Africa at a sub-national level. This data, as well as our other data, are annualised at the country-year level. In this way, and particularly because our data is on political events and not war, we avoid endogeneity issues between political events and food price volatility. The annex to the paper gives the country coverage and descriptive statistics on all the variables employed in our study.

The main independent variable of interest relates to food price insecurity. Here both food price levels and volatility in food prices need to be examined, but mainly the latter. Food price data (in the form of consumer price index, CPI, with base year of 2010) is taken from FAO database $^{3}$. Food price index (food CPI) includes a complete and consistent set of time series from 2000 to 2015, compiled by FAO using population weights to aggregate across countries. The original data is on monthly basis and we transformed this data into annualised information by simple averaging in any given year. These indices measure the price change between the current and reference periods of the average basket of goods and services purchased by households. Based on this price index, price volatility index is calculated following the methodology in Haldenwang and Ivanyna (2017). The volatility index can be understood as the typical deviation of the variable from a quadratic time trend over the period. In other words, it measures average volatility for this period (2000-2015).

We add other control variables, as well as mediating variables, which will be an innovation of the project. It needs to be borne in mind that some of the earliest studies hardly control for other factors; Arezki and Brückner (2011), for example. As primary control variables, we employ GDP per capita growth, as food price insecurity and the governmental responses to these depend on the changes in the income level of the country, and growth contributes to this capacity. We also use the share of youth and urban population, as a more urban or more youthful population can also contribute to conflict following food price increases via the relative deprivation mechanism.

Whether food price volatility produces conflict, also depends on the nature of the nation's polity: so we will use the POLITY combined autocracy and democracy scores. Autocracies are more adept at suppressing dissent, democracies may adopt mitigating policies. We also include the squared value of POLITY to check for any non-linear factors in this process. In addition to POLITY, we use the varieties of democracy (V-Dem) data set; see Coppedge et al (2016). In particular, we use the participatory index (where a rise in value indicates improvement) incorporating not just electoral government, but facets of direct democracy such as civil society engagement and sub-national government powers. Hence the V-Dem measure constitutes a broader, more encompassing, measure of democratic quality.

Unlike the rest of the literature we also employ quality of governance variables from the World Bank (see Kaufmann, Kraay and Mastruzzi, 2010), specifically factors such as the control of corruption, government effectiveness and the rule of law ${ }^{4}$. On the one hand, governance may matter more than regime type in managing food insecurity, bearing in mind that good

\footnotetext{
${ }^{3}$ Data on food CPI is available at: http://www.fao.org/faostat/en/\#data/CP (accessed on 27 January 2017).

${ }^{4}$ These scores run from -2.5 (lowest or worst) to 2.5 (highest or best). One reason for using this data rather than sources such as ICRG, is the wide country coverage of this dataset after 1997.
} 
governance, and its converse, is possible in both democracies and autocracies. But on the other hand, the type of polity is very germane to the right to protest.

Since the mechanism via which rising or volatile food prices is most likely to engender conflict (war or protest) lie in a relative deprivation or horizontal inequality effect, it is important to explicitly incorporate inequality measures into the econometric model. This has not been done in any of the studies reviewed above, and will be an innovation of our study. We propose two alternative measures related to vertical and horizontal inequality. The former is particularly pertinent in the case of conflict in the form of demonstrations and riots, short of full blown civil war. Here we could have used the All the Ginis (version 2016) database created by Branko Milanovic. ${ }^{5}$ We also use the egalitarian component index from the V-Dem data base. This has a political component measuring equal access to freedoms and rights, as well as the egalitarian distribution of economic resources across social groups, including the fulfilment of basic needs across society. Our working hypothesis is that greater inequality fuels conflict.

As far as horizontal inequality is concerned, we can employ the ethnic power relations (EPR) dataset developed by Cederman, Gleditsch and Buhaug (2013). In particular we use the percentage of the politically excluded population, the share of the excluded group size relative to the powerful ethno-political group. We also utilise the percentage of the discriminated population who are powerless or totally discriminated against. Data on the economic aspects of horizontal inequality (such as income) on a systematic basis across countries is still not available to facilitate a proper panel data econometric analysis.

A further innovation of our study is to include, independent variables on state capacity such as government expenditure. ${ }^{6}$ These are proxies for countervailing and mitigating actions by the state after food price increases. Our identification strategy involves the incorporation of measures of polity, governance, inequality and state capacity, as they are the mechanisms via which rising food prices can lead to conflict, as well as the avenues via which discontent at food price increases may be managed. In some instances, it may be worthwhile interacting some of these variables with food price increase measures to examine the strength of mechanisms in the middle of the process of how food price increases leads to more conflict.

To summarise, we carry out static panel data analysis, and the period of analysis is from 2000 to 2015 covering 40 countries in Africa using ordinary least squares. We carry out pooled (cross section and time series) estimates as well as fixed and random effects panel estimates along with Hausman tests in each individual estimate. The model is specified as:

$$
\text { Conflict }_{\mathrm{it}}=\beta_{\mathrm{o}}+\beta_{1} \text { Food Insecurity }_{\mathrm{it}}+\beta_{2} X_{\mathrm{it}}+\gamma_{\mathrm{t}}+\mathrm{v}_{\mathrm{i}}+\epsilon_{\mathrm{it}} \ldots \ldots \ldots \text { (1) }
$$

We utilise both a food price index and food price volatility separately as a measure of food insecurity in the model. $X$ represents a set of control variables as discussed, $\mathrm{v}_{\mathrm{i}}$ are country fixed effects that captures time-invariant country specific unobservable characteristics and $\gamma_{t}$ are year fixed effects to capture any variation in conflict between years which might not be covered by the explanatory variables in the model. The idiosyncratic error term is indicated by $\epsilon_{\mathrm{it}}$.

\footnotetext{
${ }^{5}$ See, https://www.gc.cuny.edu/Page-Elements/Academics-Research-Centers-Initiatives/Centers-andInstitutes/Stone-Center-on-Socio-Economic-Inequality/Core-Faculty,-Team,-and-Affiliated-LISScholars/Branko-Milanovic/Datasets, accessed 04 April 2017.

${ }^{6}$ Annualised data on social protection and food subsidies for a cross section of developing countries over a sufficiently long time period to enable a panel data set to be constructed was not obtainable.
} 


\section{Empirical Findings}

In table 1, our base line regressions, both food prices and its volatility tend to be significant except for the fixed effects estimators. Growth in per-capita GDP significantly reduces conflict risk, as our sample is mainly composed of low-income African economies; as countries become richer they face less food price related conflict risk. Also, government spending tends to significantly lower the incidence of protest, although the signs of the share of urban and youth population are counter-intuitively negative, but mostly insignificant.

Table 1: Conflict Events (ACLED-UCDP) and Food Prices

\begin{tabular}{|c|c|c|c|c|c|c|}
\hline \multirow[b]{2}{*}{ Variables } & \multicolumn{6}{|c|}{ Conflict Events (ACLED UCDP) } \\
\hline & $(1)$ & $(2)$ & $(3)$ & $(4)$ & $(5)$ & $(6)$ \\
\hline & Pooled & Pooled & FE & $\mathrm{FE}$ & $\mathrm{RE}$ & $\mathrm{RE}$ \\
\hline Food Price & $\begin{array}{c}1.027 * * * \\
(0.334)\end{array}$ & & $\begin{array}{c}0.423 \\
(0.664)\end{array}$ & & $\begin{array}{c}1.443^{* * * *} \\
(0.321)\end{array}$ & \\
\hline Food Price Volatility & & $\begin{array}{c}190.346 * * * \\
(56.692)\end{array}$ & & $\begin{array}{c}145.942 \\
(109.654)\end{array}$ & & $\begin{array}{c}222.848 * * * \\
\quad(62.428)\end{array}$ \\
\hline Government & $-1.907 *$ & $-1.977 *$ & $-4.299 * * *$ & $-4.119 * *$ & $-2.386^{*}$ & -1.258 \\
\hline & (1.017) & $(1.017)$ & $(1.632)$ & $(1.628)$ & $(1.331)$ & $(1.298)$ \\
\hline GDP per capita growth & $\begin{array}{c}-4.615^{* * *} \\
(1.397)\end{array}$ & $\begin{array}{c}-4.397 * * * \\
(1.396)\end{array}$ & $\begin{array}{c}-6.262 * * * \\
(1.341)\end{array}$ & $\begin{array}{c}-6.057 * * * \\
(1.339)\end{array}$ & $\begin{array}{c}-5.679 * * * \\
(1.300)\end{array}$ & $\begin{array}{c}-5.127 * * * \\
(1.312)\end{array}$ \\
\hline Urban population (\% of & $-2.654 * * *$ & $-2.327 * * *$ & -1.688 & -1.195 & $-2.083 *$ & -1.617 \\
\hline & $(0.610)$ & $(0.609)$ & $(6.448)$ & $(6.450)$ & $(1.190)$ & $(1.180)$ \\
\hline Youth population (\% of & $-10.196 * * *$ & $-10.643^{* * *}$ & 0.441 & 0.716 & $-7.433 * *$ & $-10.647 * * *$ \\
\hline & $(2.086)$ & $(2.086)$ & $(8.370)$ & $(8.357)$ & $(3.692)$ & $(3.690)$ \\
\hline Constant & $\begin{array}{c}586.472 * * * \\
(121.706)\end{array}$ & $\begin{array}{c}652.320 * * * \\
(119.365)\end{array}$ & $\begin{array}{c}197.379 \\
(392.773)\end{array}$ & $\begin{array}{c}146.441 \\
(394.519)\end{array}$ & $\begin{array}{c}432.990 * * \\
(203.309)\end{array}$ & $\begin{array}{c}601.547 * * * \\
(200.928)\end{array}$ \\
\hline Observations & 499 & 499 & 499 & 499 & 499 & 499 \\
\hline Number of countries & 40 & 40 & 40 & 40 & 40 & 40 \\
\hline
\end{tabular}

Note: Standard errors in parentheses. Fixed effect specifications (column 3 and 4) included period fixed effect which are not presented in the table. ${ }^{* * *} \mathrm{p}<0.01,{ }^{* *} \mathrm{p}<0.05,{ }^{*} \mathrm{p}<0.1$. Hausman tests suggests random effect static panel estimator would be a superior estimator of our model.

In table 2, we introduce polity and institutional variables in the regressions with conflict events. ${ }^{7}$ These additional variables relate to the quality of democracy drawn from polity, as well as another quality of democracy measure, the participatory index, drawn from V-Dem, also governance variables: corruption, government effectiveness and the rule of law. Data on the latter three variables are drawn from the well-known World Bank-Kaufmann et $\mathrm{Al}$ (2010) data set. All the governance variables are significant and have the right sign (except polity variable, although the squared term remains significant). This indicates a non-linear relationship with conflict. Although greater democracy promotes more civil war risk, this starts to decline after a certain level of democracy is reached, as found by Hegre et. Al (2001). Also, food price volatility continues to significantly enhance the risk of political protest events. In African nations, governance may matter more, and greater political participation can promote

\footnotetext{
${ }^{7}$ In tables 2 to 4 we only report random effects estimators, which is found to be a superior estimator by the Hausman test.
} 
protest. Interestingly, the effect of government expenditure loses significance in explaining unrest, implying that governance matters more.

Table 2: Conflict Events - Food Price Volatility in the Presence of Institutions

\begin{tabular}{|c|c|c|c|c|c|c|}
\hline \multicolumn{7}{|c|}{ Random Effects Model } \\
\hline Variables & $(1)$ & $(2)$ & (3) & (4) & (5) & (6) \\
\hline Food Price Volatility & $\begin{array}{c}222.848 * * * \\
\quad(62.428)\end{array}$ & $\begin{array}{c}217.604 * * * \\
\quad(66.503)\end{array}$ & $\begin{array}{c}235.175 * * * \\
\quad(67.063)\end{array}$ & $\begin{array}{c}216.818 * * * \\
\quad(66.564)\end{array}$ & $\begin{array}{c}233.732 * * * \\
\quad(62.538)\end{array}$ & $\begin{array}{c}249.894 * * * \\
(65.854)\end{array}$ \\
\hline $\begin{array}{l}\text { Control of } \\
\text { Corruption }\end{array}$ & & $\begin{array}{c}-85.008 * * * \\
(26.749)\end{array}$ & & & & \\
\hline $\begin{array}{l}\text { Government } \\
\text { Effectiveness }\end{array}$ & & & $\begin{array}{c}-94.740 * * * \\
(29.481)\end{array}$ & & & \\
\hline Rule of Law & & & & $\begin{array}{c}-112.643 * * * \\
(28.711)\end{array}$ & & \\
\hline $\begin{array}{l}\text { Participatory } \\
\text { component index }\end{array}$ & & & & & $\begin{array}{l}291.388 * * \\
(113.503)\end{array}$ & \\
\hline Polity2 & & & & & & $\begin{array}{c}4.503 \\
(3.032)\end{array}$ \\
\hline$\left(\right.$ Polity2) ${ }^{2}$ & & & & & & $\begin{array}{c}-1.289 * * \\
(0.626)\end{array}$ \\
\hline Government & -1.258 & -0.579 & -0.785 & -0.239 & -1.415 & -1.096 \\
\hline & $(1.298)$ & $(1.350)$ & $(1.366)$ & $(1.361)$ & $(1.301)$ & $(1.370)$ \\
\hline GDP per Capita & $-5.127 * * *$ & $-5.781 * * *$ & $-5.429 * * *$ & $-5.568 * * *$ & $-4.808 * * *$ & $-4.667 * * *$ \\
\hline & $(1.312)$ & $(1.470)$ & $(1.478)$ & $(1.462)$ & $(1.310)$ & $(1.346)$ \\
\hline Urban Population (\% & -1.617 & $-2.010 *$ & $-2.048 *$ & -1.947 & -1.746 & -1.722 \\
\hline & (1.180) & (1.156) & (1.223) & (1.195) & (1.204) & $(1.223)$ \\
\hline Youth Population (\% & $-10.647^{* * *}$ & $-13.134 * * *$ & $-14.358 * * *$ & $-13.647 * * *$ & $-12.289 * * *$ & $-12.021^{* * *}$ \\
\hline Constant & $\begin{array}{c}(3.690) \\
601.547 * * * \\
(200.928)\end{array}$ & $\begin{array}{c}(3.726) \\
654.847^{* * *} \\
(200.332)\end{array}$ & $\begin{array}{c}(3.980) \\
696.947^{* * *} \\
(210.465)\end{array}$ & $\begin{array}{c}(3.819) \\
642.751^{* * *} \\
(204.857)\end{array}$ & $\begin{array}{c}(3.796) \\
558.835 * * * \\
(204.138)\end{array}$ & $\begin{array}{c}(3.865) \\
684.004^{* * *} \\
(210.690)\end{array}$ \\
\hline Observations & 499 & 463 & 463 & 463 & 499 & 485 \\
\hline Number of countries & 40 & 40 & 40 & 40 & 40 & 39 \\
\hline
\end{tabular}

Note: Standard errors in parentheses. ${ }^{* * *} \mathrm{p}<0.01$, ** $\mathrm{p}<0.05$, * $\mathrm{p}<0.1$.

In table 3, we attempt to interact food price volatility with our institutional variables. Our aim is to gauge what mediating effect institutional quality in the form of either the quality of democracy or the effectiveness of governance has on the conflict enhancing aspects of food price volatility. Although all interactions have the correct signs, the interaction effect with the broader participatory definition of democracy drawn from the V-DEM data set is the only significant effect. 
Table 3: Conflict Events - Food Price Volatility and Interaction with Institutions

\begin{tabular}{|c|c|c|c|c|c|}
\hline \multicolumn{6}{|c|}{ Random Effects Model } \\
\hline Variables & $(1)$ & $(2)$ & (3) & (4) & (5) \\
\hline Food Price Volatility & $\begin{array}{l}217.487 * * \\
(109.911)\end{array}$ & $\begin{array}{l}227.638 * * \\
(113.781)\end{array}$ & $\begin{array}{c}278.750 * * * \\
(107.255)\end{array}$ & $\begin{array}{l}618.394 * * * \\
(203.129)\end{array}$ & $\begin{array}{c}248.631 * * * \\
(65.759)\end{array}$ \\
\hline Control of Corruption & $\begin{array}{l}-84.978 * * * \\
(31.856)\end{array}$ & & & & \\
\hline $\begin{array}{l}\text { Food Volatility*control of } \\
\text { corruption }\end{array}$ & $\begin{array}{c}-0.640 \\
(105.053)\end{array}$ & & & & \\
\hline Government Effectiveness & & $\begin{array}{c}-94.623 * * * \\
(34.171)\end{array}$ & & & \\
\hline $\begin{array}{l}\text { Food Volatility * Govt. } \\
\text { Effectiveness }\end{array}$ & & $\begin{array}{c}-9.551 \\
(108.190)\end{array}$ & & & \\
\hline Rule of Law & & & $\begin{array}{l}-126.772 * * * \\
(33.989)\end{array}$ & & \\
\hline Food Volatility * Rule of law & & & $\begin{array}{c}71.234 \\
(97.207)\end{array}$ & & \\
\hline $\begin{array}{l}\text { Participatory Component } \\
\text { Index }\end{array}$ & & & & $\begin{array}{c}423.534 * * * \\
(130.637)\end{array}$ & \\
\hline $\begin{array}{l}\text { Food Volatility * Participatory } \\
\text { Index }\end{array}$ & & & & $\begin{array}{l}-985.540 * * \\
(496.642)\end{array}$ & \\
\hline Polity2 & & & & & $\begin{array}{l}5.910^{*} \\
(3.462)\end{array}$ \\
\hline Food Volatility * Polity2 & & & & & $\begin{array}{l}-10.748 \\
(12.790)\end{array}$ \\
\hline$(\text { Polity2) })^{2}$ & & & & & $\begin{array}{l}-1.282 * * \\
(0.624)\end{array}$ \\
\hline $\begin{array}{l}\text { Government Expenditure (\% } \\
\text { of GDP) }\end{array}$ & $\begin{array}{l}-0.564 \\
(1.378)\end{array}$ & $\begin{array}{l}-0.782 \\
(1.382)\end{array}$ & $\begin{array}{l}-0.034 \\
(1.388)\end{array}$ & $\begin{array}{l}-1.701 \\
(1.310)\end{array}$ & $\begin{array}{l}-1.256 \\
(1.380)\end{array}$ \\
\hline GDP per Capita Growth & $\begin{array}{c}-5.787 * * * \\
(1.472)\end{array}$ & $\begin{array}{c}-5.434 * * * \\
(1.481)\end{array}$ & $\begin{array}{l}-5.502^{* * *} \\
(1.465)\end{array}$ & $\begin{array}{l}-4.873^{* * * *} \\
(1.306)\end{array}$ & $\begin{array}{l}-4.722 * * * \\
(1.348)\end{array}$ \\
\hline Urban Population (\% of total) & $\begin{array}{l}-1.990 * \\
(1.171)\end{array}$ & $\begin{array}{l}-2.030 \\
(1.238)\end{array}$ & $\begin{array}{l}-1.903 \\
(1.209)\end{array}$ & $\begin{array}{l}-1.873 \\
(1.222)\end{array}$ & $\begin{array}{l}-1.753 \\
(1.214)\end{array}$ \\
\hline Youth Population (\% of total) & $\begin{array}{l}-13.129 * * * \\
(3.766)\end{array}$ & $\begin{array}{l}-14.401 * * * \\
\quad(4.019)\end{array}$ & $\begin{array}{l}-13.558 * * * \\
(3.858)\end{array}$ & $\begin{array}{c}-13.410 * * * \\
(3.869)\end{array}$ & $\begin{array}{l}-12.281 * * * \\
(3.857)\end{array}$ \\
\hline Constant & $\begin{array}{c}653.409 * * * \\
(203.669)\end{array}$ & $\begin{array}{l}698.102 * * * \\
(213.523)\end{array}$ & $\begin{array}{c}620.910 * * * \\
(208.669)\end{array}$ & $\begin{array}{c}567.388 * * * \\
(206.048)\end{array}$ & $\begin{array}{c}700.078 * * * \\
(210.441)\end{array}$ \\
\hline Observations & 463 & 463 & 463 & 499 & 485 \\
\hline Number of countries & 40 & 40 & 40 & 40 & 39 \\
\hline
\end{tabular}

Note: Standard errors in parentheses. ${ }^{* * *} \mathrm{p}<0.01,{ }^{* *} \mathrm{p}<0.05,{ }^{*} \mathrm{p}<0.1$.

In table 4, we examine the impact of inequality. In order to isolate its effect from institutional factors that may mitigate or exacerbate its impact on conflict we drop the institutional variables in this analysis. We wish to incorporate income inequality in the form of GINI coefficients (the greater the coefficient the higher the degree of inequality). So given our postulate that 
inequality enhances conflict, we would expect that sign to be positive. We also utilise the more hybrid egalitarian component index which measures the equality of rights across social groups as well as the provision and coverage of basic needs. The higher the index the more egalitarian is the society in question, hence our expectation for the sign of this coefficient is negative. These two measures (the GINI and egalitarian index) are our measures of vertical inequality, the first being intra-household the latter being socio-economic group based. Then we have the measures of inter-ethnic group horizontal inequality from the EPR data set. We would expect their signs to be positive because, as constructed, a higher value implies greater inter-group inequality.

Egalitarianism has the expected negative effect on political unrest events although the coefficient is insignificant. The other horizontal inequality measures have the correct sign and are significant with the exception of the percentage of the discriminated. The coefficient on GINI appears with a counter-intuitive sign, but is statistically insignificant. This may be because greater income equality, particularly a higher middle class income share may spark more protest. Also, control variables such as per capita income growth are significant.

Table 4: Conflict Events - Food Price Volatility in the Presence of Inequality

\begin{tabular}{|c|c|c|c|c|c|c|}
\hline \multicolumn{7}{|c|}{ Random Effects Model } \\
\hline Variables & $(1)$ & $(2)$ & (3) & (4) & (5) & (6) \\
\hline Food Price Volatility & $\begin{array}{l}222.848 * * * \\
\quad(62.428)\end{array}$ & $\begin{array}{c}215.430 * * * \\
\quad(62.495)\end{array}$ & $\begin{array}{c}291.346 * * * \\
(109.420)\end{array}$ & $\begin{array}{c}45.056 \\
(32.806)\end{array}$ & $\begin{array}{l}71.326 * * \\
(34.237)\end{array}$ & $\begin{array}{l}58.468 * \\
(32.401)\end{array}$ \\
\hline Egalitarian Component Index & & $\begin{array}{l}-82.881 \\
(91.839)\end{array}$ & & & & \\
\hline Gini Index & & & $\begin{array}{l}-0.822 \\
(2.030)\end{array}$ & & & \\
\hline $\begin{array}{l}\text { Share of excluded population } \\
\text { to ethno-politically relevant } \\
\text { population (Log) }\end{array}$ & & & & $\begin{array}{l}26.225^{* * *} \\
\quad(4.864)\end{array}$ & & \\
\hline $\begin{array}{l}\text { Discriminated Population (in } \\
\text { \%) }\end{array}$ & & & & & $\begin{array}{c}14.617 \\
(65.012)\end{array}$ & \\
\hline $\begin{array}{l}\text { Powerless Population } \\
\text { (in \%) }\end{array}$ & & & & & & $\begin{array}{l}217.842 * * * \\
\quad(35.359)\end{array}$ \\
\hline Government Expenditure (\% & -1.258 & -1.251 & -1.432 & -1.042 & $-1.729 * *$ & -0.946 \\
\hline & $(1.298)$ & $(1.291)$ & $(2.434)$ & $(0.802)$ & $(0.811)$ & $(0.797)$ \\
\hline GDP per Capita Growth & $\begin{array}{c}-5.127 * * * \\
(1.312)\end{array}$ & $\begin{array}{c}-5.178 * * * \\
(1.315)\end{array}$ & $\begin{array}{l}-2.219 \\
(2.881)\end{array}$ & $\begin{array}{l}-2.242 * * \\
(0.885)\end{array}$ & $\begin{array}{c}-2.389 * * \\
(0.929)\end{array}$ & $\begin{array}{c}-2.491^{* * *} \\
(0.872)\end{array}$ \\
\hline Urban Population (\% of total) & $\begin{array}{l}-1.617 \\
(1.180)\end{array}$ & $\begin{array}{l}-1.613 \\
(1.153)\end{array}$ & $\begin{array}{l}-2.216 \\
(1.549)\end{array}$ & $\begin{array}{c}0.184 \\
(0.983)\end{array}$ & $\begin{array}{l}-0.874 \\
(0.907)\end{array}$ & $\begin{array}{l}-0.150 \\
(0.998)\end{array}$ \\
\hline Youth Population (\% of total) & $\begin{array}{c}-10.647 * * * \\
(3.690)\end{array}$ & $\begin{array}{c}-10.555^{* * * *} \\
(3.619)\end{array}$ & $\begin{array}{c}-13.597 * * * \\
(4.463)\end{array}$ & $\begin{array}{l}-0.422 \\
(2.733)\end{array}$ & $\begin{array}{l}-2.058 \\
(2.621)\end{array}$ & $\begin{array}{l}-0.606 \\
(2.763)\end{array}$ \\
\hline Constant & $\begin{array}{c}601.547 * * * \\
(200.928)\end{array}$ & $\begin{array}{c}643.544 * * * \\
(202.215)\end{array}$ & $\begin{array}{c}758.868 * * * \\
(270.029)\end{array}$ & $\begin{array}{c}59.644 \\
(149.513)\end{array}$ & $\begin{array}{c}224.579 \\
(142.225)\end{array}$ & $\begin{array}{c}98.934 \\
(149.806)\end{array}$ \\
\hline Observations & 499 & 499 & 169 & 393 & 393 & 393 \\
\hline Number of countries & 40 & 40 & 33 & 38 & 38 & 38 \\
\hline
\end{tabular}


Since time immemorial food shortages and food price increases have sparked social unrest. Indeed, the colloquial Egyptian Arabic word for bread, ayesh, also means life. Food price increases do not necessarily spark widespread protest or civil war or revolution. The degree of any resultant conflict, depend on a host of factors including the degree of inter-personal and inter-group inequality, the income level of the country, its relative urban and youth population share, its polity, quality of governance, the degree of social protection or government expenditure and state capacity. Not all studies in the realm of the cross-country empirical analysis of food insecurity and conflict incorporate all of these factors. Our innovation lies therein.

The consequences of internal conflict are not confined to the territories of countries in which it takes place, but as major international spill-overs to other countries. Chief among these are humanitarian crises involving refugees and assistance to those affected by conflict, but also complex humanitarian crises such as famine can be a consequence of civil war. It may also effect the ability of food importers to source foodstuff from conflict affected exporters, as conflict can disrupt supply chains, as well as food production. Consequently internal conflict on a large scale should be viewed as a global problem, and its mitigation, management and prevention should be seen to be a global public good.

Our results suggest that food prices, and especially food price volatility, do contribute statistically significantly to social and political unrest risk measured by political events in Africa (ACLED) data. The growth in per-capita income is significant and has the right negative sign, indicating that richer countries face less food price related political unrest. Government expenditure as a share of national income has the correct negative sign, but becomes insignificant once we introduce institutional quality and inequality. It suggests that in African nations governance may matter more, and greater political participation can promote protest. Other control variables such as the youth and urban share occasionally have unexpected signs in our regressions, but these are mostly insignificant.

We have underscored the mediating role of 'institutions' in the food price (volatility)-conflict nexus. The institutional variables that we employ can be divided in to two categories. First, we utilised political institutions, which are a measure of process. We chose to measure these using the well-known POLITY measure of the degree of autocracy-democracy, and the much broader participatory index drawn from the newly launched V-DEM data set. The latter measure contains many more facets related to the degree of citizens and social group participation in political processes, and also does not suffer from the limitation of the POLITY data set which is endogenous to conflict, as the democracy and autocracy score of a country in any year is affected by the emergence of conflict. Be that as it may, our results indicate that greater democracy can engender more conflict, especially when it comes to protests, riots or other disturbances, but after a certain threshold of higher democratic development greater democracy is conflict abating. The V-DEM participatory index can also encourage more protest, but it does not enhance civil war related fatalities.

The second set of our institutional variables pertain to outcomes related to the quality of governance: the rule of law, the control of corruption and the effectiveness of government administration. They emerge with the right negative signs implying lesser conflict in the presence of good governance. The importance of governance in this regard is highlighted by the fact that when we interact food price volatility or level with governance, the food price volatility or food price level coefficient sometimes becomes statistically insignificant. Furthermore, the degree of government expenditure as a proportion of national income loses 
its salience, becoming statistically insignificant. This emphasizes the salience of the mediating role of institutions and state capacity when it comes to unrest induced by food price volatility.

An innovation of our study is the inclusion of inequality. We deploy two metrics of interpersonal or inter-household vertical inequality: the GINI coefficient of income inequality and the V-DEM egalitarian index, which is a broader measure of how egalitarian a society is. The V-DEM egalitarian index emerges with the correct expected signs, suggesting that more inequality breeds more conflict. The GINI index of income inequality, however, has a counterintuitive statistically insignificant sign, implying that greater income equality may result in a greater risk of political unrest surrounding food price volatility. This may be very well the case, as greater equality implies a higher middle class share of income, and it is precisely these groups who are politically more vocal. We also utilize measures of inter-group or horizontal inequality in its political dimensions. These result in expected signs; more horizontal inequality leads to greater conflict and is quite often statistically significant.

\section{REFERENCES}

Arezki, Rabah and Markus Brückner (2011) 'Food Prices and Political Instability', CESifo Working Paper no. 3544.

Bellemare, Marc (2014) 'Rising Food Prices, Food Price Volatility and Social Unrest', American Journal of Agricultural Economics, 97(1): 1-21.

Brinkman, Henk-Jan and Cullen Hendrix (2011) Food Insecurity and Violent Conflict: Causes, Consequences, and Addressing the Challenges, World Food Programme, Occasional Paper no 24.

Cederman, Lars-Erik, Kristian-Skrede Gleditsch and Halvard Buhaug (2013) Inequality, Grievances, and Civil War, New York: Cambridge University Press.

Collier, Paul, Lani Elliot, Håvard Hegre, Anke Hoeffler, Marta Reynal-Querol and Nicholas Sambanis (2003) Breaking the Conflict Trap: Civil War and Development Policy, World Bank, Oxford: Oxford University Press.

Coppedge, Michael, John Gerring, Staffan I. Lindberg, Svend-Erik Skaaning, Jan Teorell, David Altman, Frida Andersson, Michael Bernhard, M. Steven Fish, Adam Glynn, Allen Hicken, Carl Henrik Knutsen, Kyle L. Marquardt, Kelly McMann, Valeriya Mechkova, Farhad Miri, Pamela Paxton, Josefine Pernes, Daniel Pemstein, Jeffrey Staton, Natalia Stepanova, Eitan Tzelgov, Yi-ting Wang, and Brigitte Zimmerman. 2016. "V-Dem [Country-Year/Country-Date] Dataset v6.” Varieties of Democracy (V-Dem) Project.

Gleditsch, Nils Petter (2008) 'The Liberal Moment Fifteen Years On’, International Studies Quarterly, 15 (4): 691-712.

von Haldenwang Christian and Maksym Ivanyna (2017) Does the political resource curse affect public finance? The vulnerability of tax revenue in resource-rich countries. WIDER Working Paper, UNU-WIDER, Helsinki, Finland. Available at: https://www.wider.unu.edu/sites/default/files/wp2017-7.pdf [accessed 31 January, 2017]

Hegre, Håvard, Tanja Ellingsen, Scott Gates and Nils Petter Gleditsch (2001) 'Towards a Democratic Civil Peace? Democracy, Civil Change, and Civil War 1816-1992', American Political Science Review, 95(1): 17-33. 
Hendrix, Cullen and Stephan Haggard (2015) 'Global Food Prices, Regime Type, and Urban Unrest in the Developing World', Journal of Peace Research, 52 (2): 143-157

Kaufmann, Daniel, Aart Kraay and Massimo Mastruzzi (2010) The Worldwide Governance Indicators Methodology and Analytical Issues. World Bank Policy Research Working Paper No. 5430 (available at

https://papers.ssrn.com/sol3/papers.cfm?abstract_id=1682130 accessed on 29 June 2017

Miguel, Edward, Shanker Satynath and Ernest Sergenti (2004) 'Economic Shocks and Civil Conflict: An Instrumental Variables Approach', Journal of Political Economy, 112(4): 725-753.

Murshed, S Mansoob (2010) Explaining Civil War: A Rational Choice Approach, Cheltenham: Edward Elgar.

Natalini, Davide, Aled Jones and Giangiacomo Bravo (2015) 'Quantitative Assesment of Political Fragility Indices and Food Prices as Indicators of Food Riots in Countries', Sustainablity, 7, 4360-4385, open access.

Østby, Gudrun (2013) 'Inequality and Political Violence: A Review of the Literature', International Areas Studies Review, 16(2): 206-231.

Raleigh, Clionadh, Hyun Jin Choi and Dominic Kniveton (2015) 'The Devil is in the Details: An Investigation of the Relationships between Conflict, Food Price and Climate Across Africa, Global Environmental Change

Smith, Todd (2014) 'Feeding Unrest: Disentangling the Causal Relationship between Food Price Shocks and Sociopolitical Conflict in Urban Africa', Journal of Peace Research, 51 (6): 679-695.

Weinberg, Joe and Ryan Bakker (2014) 'Let Them Eat Cake: Food Prices, Domestic Policy and Social Unrest, Conflict Management and Peace Science, 32(3): 309-326. 
Annex: Descriptive Statistics, 2000-2015 and Country List

\begin{tabular}{lccc}
\hline Variables & Mean & Std. Dev & Observations \\
\hline $\begin{array}{l}\text { Conflict Variables } \\
\quad \text { Number of Conflict Events in a year (ACLED UCDP) }\end{array}$ & 111.94 & 260.21 & 640 \\
$\quad$ Food Price & & & \\
$\quad$ International Food Price Index & 09.62 & 31.37 & 633 \\
$\quad$ International Food Price Volatility Index & 0.15 & 0.15 & 633 \\
$\quad$ Institutions & -0.60 & 0.53 & 557 \\
$\quad$ Control of Corruption & -0.67 & 0.53 & 557 \\
$\quad$ Government Effectiveness & -0.63 & 0.52 & 557 \\
$\quad$ Rule of Law & 1.12 & 5.12 & 582 \\
$\quad$ Polity2 & 0.41 & 0.13 & 640 \\
$\quad$ Participatory Component Index & & & \\
Macroeconomic Variables & 26.99 & 9.31 & 513 \\
$\quad$ Government Expenditure (\% of GDP) & 2.40 & 7.26 & 584 \\
$\quad$ GDP per capita growth (annual \%) & & & \\
Inequality variables & 0.54 & 0.17 & 640 \\
$\quad$ Egalitarian Component Index & 43.64 & 8.66 & 195 \\
$\quad$ Gini Index & 1.62 & 1.72 & 418 \\
$\quad$ Share of Excluded Population relative to & & & \\
$\quad$ ethno-politically relevant Population (Log) & 0.02 & 0.08 & 418 \\
$\quad$ Discriminated Population (in \%) & 0.10 & 0.21 & 418 \\
$\quad$ Powerless Population (in \%) & & & \\
Others & 39.81 & 18.35 & 597 \\
$\quad$ Urban Population (\% of total) & 41.45 & 6.03 & 597 \\
$\quad$ Youth Population (\% of total) & & & \\
\hline
\end{tabular}

\section{List of Countries}

$\begin{array}{ll}\text { Algeria } & \text { Libya } \\ \text { Angola } & \text { Madagascar } \\ \text { Benin } & \text { Malawi } \\ \text { Botswana } & \text { Mali } \\ \text { Burkina Faso } & \text { Mauritania } \\ \text { Burundi } & \text { Morocco } \\ \text { Cameroon } & \text { Mozambique } \\ \text { Central African Republic } & \text { Namibia } \\ \text { Chad } & \text { Niger } \\ \text { Djibouti } & \text { Nigeria } \\ \text { Egypt } & \text { Rwanda } \\ \text { Equatorial Guinea } & \text { Senegal } \\ \text { Ethiopia } & \text { South Africa } \\ \text { Gabon } & \text { Sudan } \\ \text { Gambia } & \text { Swaziland } \\ \text { Ghana } & \text { Tanzania } \\ \text { Guinea-Bissau } & \text { Togo } \\ \text { Kenya } & \text { Tunisia } \\ \text { Lesotho } & \text { Uganda } \\ \text { Liberia } & \text { Zambia }\end{array}$

